\title{
伝導試験よりみた末梢神経損傷の予後について
}

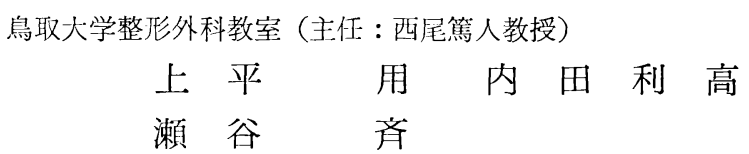

\section{On the Prognosis of Peripheral Nerve Injuries, Especially Observation by Means of Conduction Test}

By

\author{
M. Kamihira, T. Utchida and H. Shetani \\ Department of Orthopedic Surgery, \\ Tottori University, School of Medicine
}

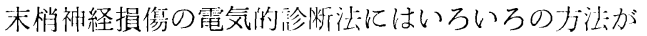
あるが，現在比較的上く応用されていろのは筋電図， 強さ期間州線（クロナキシーを念めて）などである。 しかしこ扎らにも气れぞれ一长一短があるので，最近

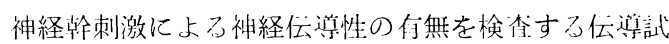
験が洰目岂机てきている。

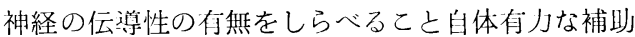
的診断法となることはいうまでもないが，損傷の程度 を量的汇知るため伝尊時間 (伝繁速度), 波形の変 化などを記録し比較することがより有意義であると考 えている.
\end{abstract}

\section{検查対象並びに方法}

\section{検 查対象}

橈骨神経損賃 12 例, 尺骨神経損伤 8 例, 正中神経 損伤 2 例, 上腕袖経叢損賃 3 例、腋窩神経損伤 2 例, 腓骨神経損伤 20 例, 坐肙神経損甥 4 例, 合郭 51 神経 について娭查した。

\section{測定方法}

第2 7 回陌日本整形外科災告外科学会などで発表し たのと同じ力法である.

\section{成}

\section{績}

損傷部にて電気刺激し当該神経支配筋の㲜作流を唀 導した場合について比較検討する.

\section{1. 全, 不全麻瘦と伝導速度}

運動機能を中心にし全廃を全麻疩, 運動機能残存す るが，健彔例と比較して明瞭化障害されているものを
不企林理として比較した。

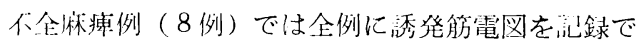
きた，㨏巾む健侧とあまり差がないか，あつても柽度 減少の程度である。しかし波版が複雑化している例を

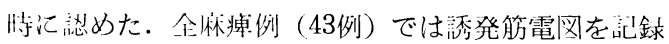
できないもの，䛉録できてむ振巾の減少，波版の变化 など障笘の程度により雑多である。

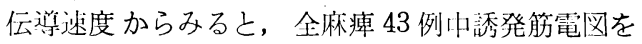
記録できなかつた例（伝学性消失と仮定）は 16 例あ り，讪録できたものは 27 例であるが，乙れらの述度 は 39 m.p.s. 以下の例が大多数をしめている. 不全麻 㾝では 8 例中 30 m.p.s. 以上の 逃度を有するものが 7 例で正常例に近いととを示している. この関係を Waller の変性が完了する損㑺後 2 週間以上経過した 症例について倹討してみると一層明確になる。したが つて伝愬速度，波形などを健侧と比較することによつ て神経損賃の程度を量的にしることができる。

\section{2. 治療法と成績}

51例のうち治䝤们もの, 不明のものをのぞき最短 3 力月, 最長 5 年を経過した, 保保的療法 23 例, 神 経䟝離術 19 例, 神経縫合術 3 例計 45 例について予後 を调全しえた。

保存的療法: 23 例中 30 m.p.s. 以上の速度を有する ものは完治率高く, 20 m.p.s. 前後の 速度のものも柽 快率良好であるが, 10 m.p.s. 以下の例では予後はよ くない.

神経剶離術：19 例中 30 m.p.s. 以上の速度のものは 全例完全治瘾した。伝導性消失と仮定した 7 例中 1 例 


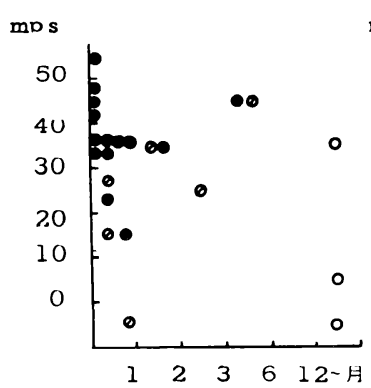

A：保存的减法例


治境まての期間よりみた伝速度と治療成精

は完治，4 例は怪忙したが 4 例は未治であつた。一般 に伝学性何するものの治媳率は郎奵であるが未治も 2 例あつた。しかしこれら 2 例は非常に堜川な症例であ ることに泟意すべきである。

袖経縫合術：どの部位にて刺激しても㳩作流を唀等 できず，原囚などから考え断裂をうたがつた 3 例に施 行し 1 例完治， 2 例怪快しおおむ拉良好である.

\section{3. 治療までの期間と成績}

保存的療法: 損仿後 1 力月以内に治療をはじめた 15例中, 速度 30 m.p.s. 以下の屯の屯此较的予後良好. で未治はない. 1 力月〜 6 力月たつて治療したものは たとえ 30 m.p.s. 以上の速度のものでも完治率は娍少 するがな打怪快の見込みがあることを㖣示し，12力月 以上経過したものはこの療法にて 治瘏の見込みがな い. (図A).

神経䟝離術：1 力月以内に于術したものは速度に関 係なく，伝導性消失していても速続性を保持している かぎり完治している．2３ 3 月で治療したものは完 治率 $60 \%$ で，硁快 2 例 $(40 \%)$ であり，乙れらは動 作流を唀㦝できなかつた例である。未治はない，3 力 月以上たつ上予後は急速に不良になる。(図B).

神経縺合術：比較的早期江縫合した症例之 1 年経過 した例は怪快, 約 2 力月たつて縫合した例は:完治した が, 後 2 者は完全断裂でなく神経腫形成を躵め切除縫 合した症例である。(図C).

\section{4. 神経別にみた治療成績}

橈量神経：保存的療法例は速度屯比較的大きい屯の であつたが全例完治, 神経剝離術例は㰾作流唀棌でき なかつた 2 例のうち 1 例の怪快をのぞき他はすべて完 治し，神経縫合術は 1 例であるが完治している，部位 は全例上腕外侧部で損㑺していたが橈骨神経の再生力
は非常に良好である。

天骨神経：保存除療江例はなく神経䟝離術施行 6 例，䘞経縫合術 1 例であるが企治例は 2 例にすぎず, たと元速度は 比較的大きくても予後不良のものが多 い. これは遅桨性麻㾝が多く特有の病理学的変化を 有し，しかもその支配笳が手指の細かい迎㳩関与す るためであらう。

正中神経：神経剝離術 2 例，完治，軽快 1 例ずつで 何れも Carpal tunnel syndrom である.

上㸝神経賞: 外伤によるもので損㑺部位が中枢に近 くしかも Rootavulsionを抢こしている症例で予後不 良であつた。

腓骨神経：保存的療法 16 例のうち速度大きいもの は予後良好であるが小さいものは不良である。神経剝

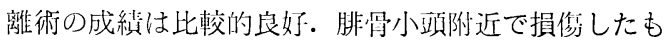
のはほぼよい絬果をえているが，より中枢侧の腓骨神 経幹部の損伤は予後がやや掞とる.

坐骨神経 : 保存的療法, 神経剝離術あるいは神経縫 合術を施行したどの症例む完治したものはなかつた。

このように神経損㑺の予後は坐骨神経，上腕神経叢 など不卙で，橈等神経などの治療成緽はよく神経の種 颣によつてととなると同時に，同一神経でも損修部位 によつてととなることは諸家の報告と同様である。

\section{考察}

末梢神経損伤に際し神経幹の経皮的電気刺激により 支酒筋筋勳作流を唀導できる例とでき咧がある．前 者にても刺激闇值の上景，動作流の振巾減少，波形の 変化, artifact より筋動作流出現までの伝導時間の延 長をみることがある．かかる例は神経連続性が完全に 断裂していることはなく，伝導性を有する神経線維が 
残存していることを喑示する，後者には完全に離断し ている場合と連続性を保持している場合がある．完全 離断例では損傷部の中枢部刺激時に当然損賃直後より 誘発笳電図を㛢尊記録できず，末梢例刺激時にも損伤 後 2,3 日にて誘導できなくなる．また連続性を保持 している例であたとえ損㑺部刺激時には誘導できなく てもより中枢部位の非損傷部で刺激すれば動作流の振 巾の低下, 波形の変化などは認めるがとにかく誘導で きるととがある. この場合は損傷部の変化高度で, 内 出血, 浮腫あるいは瘢痕などにより電気抵抗が増加し 神経を興奮せしめるにたる電流に達しなかつたあので あ万う.かかる例はかりの伝導性消失であつて実際は 神経変性をともないながらも伝導性を有する神経線維 がのとつているととを示す. 又連続性は保持していて もどの部位を刺激しても誘導できない例は Waller の 変性が完了したものであらう．神経剥離術施行例のう 与伝導性消失上仮定された 7 例中 1 例完治, 4 例軽快 したが，これら好成績を得たむのは中枢部位で非損倠 部を刺激した場合伝導時間遅延ししかも振巾の減少な ぞ認めるが誘発筋電図を记録できたものが大部分であ つた。このように電気刺激することによつて損賃, 変 性の程度を予知できる。

保存的療法が手術的療法の適応加の決定は観察した 症例 加ら推察して (1) 当該損鹪神経の何れの 部位 を刺激しても動作流を唀導できぬ症例（完全断裂か Waller の変性などのある症例). (2) 損傷部より中 枢部の非損傷部で刺激すれば㲜作流を誘導しうるが損 伤部刺激の場合は動作流得ぬ症例, 但しかかる例では 損傷部にて神経幹近くに針電極を刺入し刺激すれば誘 導できる場合がある（これらの例は神経周囲からの压 迫, 瘾着など強い. しかし連続性は保持されている). この（1）（2）のような症例は損傷からの時間的経 過に関係なく神経露出の適応とし適当な外科的療法を 施行すべきである. ( 3 ) 損㑺部刺激時唀発筋電図を記 録できる症例（連続性保持）では速度小さく，振巾も
低いもの程早期に外科的療法を要することを喑示して いたが，（イ）損傷後1 力月以内に新れたものではた とえ損傷直後大きい速度, 振巾を有していても一定期 間ごとに速度, 振巾の変化を追究し段段小さくなつて 屯損伤後 3 週〜 1 力月たつて又大きくならないあの.

(口) 損䈃後 1 力月以上たつて訪れたものでは完全治 癒を望むという観点らかすれば速度が 20 m.p.s. 以下 でしかも振巾低く, 波形の複雑な症例は, 一応神経露 出の必要があるもの之考える.

結語

末梢神経損傷51例について神経幹刺激による支配筋 の動作流出現の有無, 軼作流の振巾や出現までの時間 （すなわち便宜的伝柏速度）を测定し，そのうち最短 3 力月, 最長 5 年を経過した 45 例の予後を調查し得 た. その結果この神経幹刺激による伝導試験は損傷の 程度, 治療法の適応, 又手術時期, 手術法の決定をす るのにすぐれた方法であることを矨つた。

\section{発言鹿大田貝稔弘}

末梢神経損㑺の予後判定には運動神経線維伝導速度 測定のみにては不充分之考える.特に不全麻㾞の治療 判定に伝速を利用する場合は感覚運秒神経伝導速度む 併せ行うことが大切であると考える.

答岛大 上平用

1. 不全麻疸の予後判定

運動機能を中心にし知覚障害については余り検討し てない. 徒手筋力テストなばを基準として予後を判定 した.

2. 知覚神経線維の伝導速度の測定による判定む当 然必要である.しかし, 尺骨神経, 正中神経などの測 定は次較的容易であるが, 坐骨神経などでは知覚線維 の速度などの測定は”容少でないので, 連動神経線維に ついて検討した。 